\title{
Memahami Pilihan Aktivis untuk Bermuhammadiyah
}

DOI 10.18196/AIIJIS.2017.0070.145-148

\section{HARYADI}

Universitas Muhammadiyah Yogyakarta

$\begin{array}{ll}\text { Judul } & \text { : Becoming Muhammadiyah } \\ \text { Prolog } & \text { : Hajriyanto Y. Thohari } \\ \text { Epilog } & \text { : Muhammad Ali } \\ \text { Penerbit } & \text { : Mizan } \\ \text { Kota } & \text { : Bandung } \\ \text { Tahun } & : 2016 \\ \text { Halaman } & : 340 \\ \text { ISBN } & : 978-979-433-913-8\end{array}$

Muhammadiyah merupakan organisasi Islam yang besar, yang memiliki ciri melaksanakan amar ma'ruf nahi munkar. Muhammadiyah mengajarkan dalam beragama secara lugas, apa adanya, yang pokok-pokok saja, yang penting sesuai dengan Alquran dan Sunnah. Lugas inilah yang menyebabkan Muhammadiyah miskin tradisi, beginilah prolog dalam buku ini. Muhammadiyah yang merupakan persyarikatan modern akan tergilas dengan zaman apabila tidak melakukan perubahan, tidak berijtihad dalam menangani isu-isu dan ancaman global. Kegelisahan inilah yang malahirkan buku ini.

Buku yang merupakan kumpulan testimoni para tokoh intelektual Muhammadiyah menjadikan buku ini menarik untuk dibaca. Para tokoh intelektual menyebut Muhammadiyah merupakan state of mind, jadi orang yang menjadi Muhammadiyah dikatakan sebagai process of becoming. Orang menjadi Muhammadiyah tidak lepas dari proses perjalanan yang panjang. Perjalanan setiap orang tentunya berbeda-beda, tetapi mungkin tanpa sengaja menemukan sesuatu yang dicarinya.

Becoming Muhammadiyah, proses menjadi Muhammadiyah yang direfleksikan dalam testimoni para tokoh Muhammadiyah dalam buku 
ini, merupakan gambaran bagaimana seseorang untuk menjadi Muhammadiyah. Ada beberapa faktor seseorang menjadi Muhammadiyah, antara lain:

Pertama, menjadi Muhammadiyah karena faktor keturunan.

Hal ini merupakan proses alami yang mana setiap orang mengalaminya, akan tetapi ada juga dalam perjalanan hidupnya menambatkan pilihan ke yang lain. Akan tetapi kebanyakan menjadi Muhammadiyah karena faktor keturunan ini. Orang tua dan kerabatnya Muhammadiyah maka otomatis menjadi Muhammadiyah.

Kedua, menjadi Muhammadiyah karena tugas belajar atau melanjutan pendidikan.

Penulis dalam buku ini sebagian menuliskan bahwa menjadi Muhammadiyah mereka berawal dari perjalannya menjadi pelajar atau mahasiswa. Setelah itu kemudian ikut aktif dalam kegiatan yang di dalamnya berkaitan dengan Muhammadiyah, seperti ikut Darul Arqam, IPM, IMM. Aktif dalam organisasi tersebutlah kemudian semakin paham dengan Muhammadiyah, yang kemudian semakin jatuh cinta dengan Muhammadiyah. Karena di situlah mereka menemukan wadah dalam mengaktulisasikan dirinya, dalam berkiprah mengabdikan diri untuk agama, bangsa dan negara.

Ketiga, menjadi Muhammadiyah karena Amal Usaha Muhammadiyah.

Muhammadiyah dengan amal usahanya yang sudah maju dan berkembang, tentu melibatkan banyak porsenil di dalamnya. Sehingga banyak orang menjadi Muhammadiyah karena bekerja di amal usaha Muhammadiyah, seperti menjadi pengajar di sekolah milik Muhammadiyah, bekerja di rumah sakit milik Muhammadiyah dan sebagainya.

Keempat, menjadi Muhammadiyah karena membaca buku tentang Muhammadiyah.

Menjadi Muhammadiyah melalui proses dari kenal kemudian ingin tahu dan akhirnya menjatuhkan pilihan kepada Muhammadiyah, berawal dari membaca buku tentang Muhammadiyah.

Kelima, mejadi Muhammadiyah karena lingkungan.

Lingkungan yang merupakan tempat tinggal dan tempat bersosialisasi manusia memberikan warna tersendiri bagi setiap orang. Lingkungan memberi pengaruh sangat besar terhadap kehidupan manusia. Lingkungan juga sangat berpengaruh terhadap karakter manusia. Lingkungan yang 
di dalamnya didominasi Muhammadiyah juga akan memberikan warna masyarakat yang ada di dalamnya. Seperti daerah Kauman Yogyakarta yang mana tempat kelahiran Muhammadiyah sangat berbeda sekali dengan daerah yang lain, baik dari kehidupan keagamaan dan sosialnya. Jadi orang yang tinggal di lingkungan yang di dalamnya banyak orang Muhammadiyah atau lingkungan Muhammadiyah juga akan mempengaruhi kehidupannya. Menjadi Muhammadiyah karena hidup dan berinteraksi di lingkungan Muhammadiyah.

Keenam, menjadi Muhammadiyah karena perkawinan.

Perkawinan atau pernikahan merupakan ikatan lahir batin antara seorang pria dan seorang wanita sebagai suami-istri dengan tujuan membentuk keluarga. Perkawinan antara seseorang dari anak yang keluarganya Muhammadiyah juga bisa menjadikan seseorang menjadi Muhammadiyah. Hal ini terjadi karena dengan interaksinya di dalam keluarga yang Muhammadiyah akan juga mempengaruhi kehidupan orang tersebut menjadi Muhammadiyah. Maka akhirnya perpaduan antara Muhammadiyah dengan yang lain juga terjadi, misal perpaduan antara keluarga Muhammadiyah dengan keluarga NU, keluarga Muhammadiyah dengan keluarga PERSIS, dan sebaginya. Jadi menjadi Muhammadiyah karena perkawinan ini sangat banyak terjadi di masyarakat kita. Perpaduan ini juga akan berdampak tersendiri kepada Muhammadiyah. Muhammadiyah akan semakin progresif dan berkembang mengikuti perkembangan sosial masyarakat.

Ketujuh, menjadi Muhammadiyah karena simpatik dengan tokoh-tokoh Muhammadiyah yang dermawan, suka bersedekah dan menolong umat. Keteladaan kata kunci untuk menjadi simpatik, hal inilah yang menjadi para tokoh ke depankan dalam berdakwah dan beramal ma'ruf nahi munkar. Suritauladan yang dibawa Rasulullah dalam mengajari umat dalam berdakwah ini yang membuat banyak orang bersimpatik dengan Muhammadiyah, yang merupakan pergerakan Islam yang moderat, inklusif dan progresif.

Kedelapan, menjadi Muhammadiyah karena urbanisasi dan mobilitas sosial.

Banyak orang pedesaan pindah ke kota dalam rangka belajar (menjadi pelajar atau mahasiswa) dan bekerja. Ada yang belajar ke kota karena kemauan sendiri atau juga karena keinginan orang tua. Berawal dari sekolah inilah banyak pelajar dan mahasiswa mengenal Muhammadiyah, 
baik dari mata pelajaran Kemuhammadiyahan ataupun ikut dalam organisasi yang terkait dengan Muhammadiyah, seperti Darul Arqam, IPM, IMM dan juga kajian-kajian Islam yang diadakan oleh Muhammadyah. Bekerja dan tinggal di kota juga bisa menjadikan seseorang mengenal Muhammadiyah. Tinggal di lingkungan Muhammadiyah kemudian berinteraksi dengan masyarakat, mengikuti kegiatan-kegiatan sosial dan keagamaan, akan mempengaruhi orang yang ada dan tinggal di lingkungan tersebut. Belajar dan bekerja di kota atau urban, menyebabkan seseorang bersinggungan dengan Muhammadiyah yang akhirnya kenal dan jatuh cinta dengan Muhammadiyah, kemudian menjadi Muhammadiyah.

Buku Becoming Muhammadiyah, yang di dalamnya berisi testimoni para tokoh dari intelektual Muhammadiyah atau autobiografi tokoh Muhammadiyah, ini sangat bagus untuk dibaca, karena disini tokoh-tokoh yang mengenal Muhammadiyah berbagi pengalaman, yang nantinya akan memberikan lebih banyak pemahaman tentang Muhammadiyah. Becoming Muhammadiyah cocok sekali dibaca bagi para aktivis dan pengamat untuk memahami bagaimana proses kader-kader Muhammadiyah menentukan pilihan mereka untuk aktif dalam pergerakan Islam. 